\title{
Adult Neurogenesis Leads to the Functional Reconstruction of a Telencephalic Neural Circuit
}

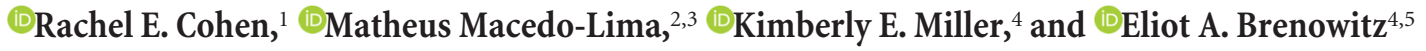 \\ ${ }^{1}$ Department of Biological Sciences, Minnesota State University, Mankato, Minnesota 56001, ${ }^{2}$ Graduate Program in Neuroscience and Behavior, University \\ of Massachusetts, Amherst, Massachusetts 01003, ${ }^{3}$ CAPES Foundation, Ministry of Education of Brazil, Brasilia DF 70040-020, Brazil, and Departments of \\ ${ }^{4}$ Psychology and ${ }^{5}$ Biology, University of Washington, Seattle, Washington 98195
}

\begin{abstract}
Seasonally breeding songbirds exhibit pronounced annual changes in song behavior, and in the morphology and physiology of the telencephalic neural circuit underlying production of learned song. Each breeding season, new adult-born neurons are added to the pallial nucleus HVC in response to seasonal changes in steroid hormone levels, and send long axonal projections to their target nucleus, the robust nucleus of the arcopallium (RA). We investigated the role that adult neurogenesis plays in the seasonal reconstruction of this circuit. We labeled newborn HVC neurons with BrdU, and RA-projecting $\mathrm{HVC}$ neurons $\left(\mathrm{HVC}_{\mathrm{RA}}\right)$ with retrograde tracer injected in $\mathrm{RA}$ of adult male white-crowned sparrows (Zonotrichia leucophrys gambelii) in breeding or nonbreeding conditions. We found that there were many more $\mathrm{HVC}_{\mathrm{RA}}$ neurons in breeding than nonbreeding birds. Furthermore, we observed that more newborn HVC neurons were back-filled by the tracer in breeding animals. Behaviorally, song structure degraded as the HVC-RA circuit degenerated, and recovered as the circuit regenerated, in close correlation with the number of new $\mathrm{HVC}_{\mathrm{RA}}$ neurons. These results support the hypothesis that the HVC-RA circuit degenerates in nonbreeding birds, and that newborn neurons reconstruct the circuit in breeding birds, leading to functional recovery of song behavior.
\end{abstract}

Key words: adult neurogenesis; HVC; plasticity; regeneration; songbird; testosterone

\section{Significance Statement}

We investigated the role that adult neurogenesis plays in the seasonal reconstruction of a telencephalic neural circuit that controls song behavior in white-crowned sparrows. We showed that nonbreeding birds had a $36 \%-49 \%$ reduction in the number of projection neurons compared with breeding birds, and the regeneration of the circuit in the breeding season is due to the integration of adult-born projection neurons. Additionally, song structure degraded as the circuit degenerated and recovered as the circuit regenerated, in close correlation with new projection neuron number. This study demonstrates that steroid hormones can help reestablish functional neuronal circuits following degeneration in the adult brain and shows non-injury-induced degeneration and reconstruction of a neural circuit critical for producing a learned behavior.

\section{Introduction}

Neurogenesis in the adult brain is a striking form of plasticity. The contribution of newborn neurons to functional plasticity of neural circuits is an interesting topic that is challenging to address

Received Feb. 18, 2016; revised July 1, 2016; accepted July 8, 2016.

Author contributions: R.E.C. and E.A.B. designed research; R.E.C., M.M.-L., and K.E.M. performed research; R.E.C. analyzed data; R.E.C. and E.A.B. wrote the paper.

This work was supported by National Institutes of Health Grants MH53032 and NS075331 to E.A.B., National Institutes of Health Grant T32 DC005361 to R.E.C., and Coordination for Development of Higher Education Personnel CAPES-Brazil 7318/11-1 and 13640/13-5 to M.M.-L. We thank Karin Lent, Ralf Luche, and Tracy Larson for technical assistance; Wai Chan for confocal microscopy assistance; David Perkel for discussion; and two anonymous reviewers for helpful comments.

The authors declare no competing financial interests.

Correspondence should be addressed to Dr. Rachel E. Cohen, 242 Trafton Science South, Minnesota State University, Mankato, MN 56001. E-mail: rachel.cohen@mnsu.edu.

DOI:10.1523/JNEUROSCI.0553-16.2016

Copyright $\odot 2016$ the authors $\quad 0270-6474 / 16 / 368947-10 \$ 15.00 / 0$ in the leading mammalian models of adult neurogenesis. New neurons added to the olfactory bulb in mammals are interneurons (Lledo et al., 2006; De Marchis et al., 2007), and those added to the dentate gyrus synapse locally (Toni et al., 2008). The avian song control system, however, provides a unique model for investigating the incorporation of new projection neurons into long-range neural circuits in the telencephalon.

New neurons are added to the telencephalic nucleus HVC (acronym used as a proper name, Reiner et al., 2004) of adult songbirds (e.g., Goldman and Nottebohm, 1983; Paton and Nottebohm, 1984; Tramontin and Brenowitz, 1999; Absil et al., 2003; Balthazart and Ball, 2016). Most of these new HVC cells likely project at least $4 \mathrm{~mm}$ to synapse on neurons in the robust nucleus of the arcopallium (RA; Fig. 1a) (Alvarez-Buylla et al., 1990; Kirn and Nottebohm, 1993; Scotto-Lomassese et al., 2007). One study showed that new interneurons are also added to HVC (Scott and 
Lois, 2007). The HVC-RA circuit is necessary for the production of stereotyped song, a learned sensorimotor behavior used to attract mates and defend territories (Ölveczky et al., 2011). The functional significance of the addition of new projection neurons to the HVC-RA circuit in adult songbirds remains unclear, however (Brenowitz and Larson, 2015). Songbirds that breed seasonally and show pronounced seasonal plasticity of the song system provide an excellent model for investigating this topic.

Gambel's white-crowned sparrows (Zonotrichia leucophrys gambelii) show pronounced seasonality of their reproductive physiology, song behavior, and the underlying neural circuitry for song production (Marler and Tamura, 1964; Wingfield and Farner, 1978; Smith et al., 1995). Circulating testosterone (T) levels increase at the onset of breeding and this induces a trophic cascade (largely mediated through BDNF) (Wissman and Brenowitz, 2009), which leads to an increase in HVC volume and total neuron number from $\sim 90,000$ to 160,000 cells (Tramontin et al., 2000; Brenowitz and Larson, 2015) (see Fig. 7). This increase results from increased incorporation and survival of newborn neurons in HVC (Larson et al., 2014). In nonbreeding birds, $\mathrm{T}$ concentration falls to basal levels, trophic support is withdrawn, HVC volume decreases, and neuron number rapidly decreases back to $\sim 90,000$ cells. This loss of neurons results from caspase-mediated apoptosis (Thompson et al., 2007; Thompson and Brenowitz, 2008; Larson et al., 2014). Changes in song behavior parallel these changes in the song system. Males sing stereotyped song at high rates while breeding and produce less stereotyped and fewer songs during the nonbreeding season (Smith et al., 1995; Meitzen et al., 2009).

It was unknown whether (1) the pronounced changes in HVC neuron number result in seasonal remodeling of the adult HVC-RA circuit, (2) the degree to which newborn HVC projection neurons $\left(\mathrm{HVC}_{\mathrm{RA}}\right)$ directly contribute to regeneration of the circuit in breeding birds, and (3) increased song stereotypy in breeding birds is related to the incorporation of newborn $\mathrm{HVC}_{\mathrm{RA}}$ neurons. Our study was designed to address these questions in adult male sparrows. We report here that white-crowned sparrows show pronounced seasonal changes in the total number of $\mathrm{HVC}_{\mathrm{RA}}$ neurons, as well as the number of newborn neurons integrated to this circuit. Furthermore, the degree to which song stereotypy improves in breeding condition birds is highly correlated with the number of new $\mathrm{HVC}_{\mathrm{RA}}$ neurons. Our results demonstrate that the addition of new projection neurons regenerates a neural circuit important for the production of a learned sensorimotor behavior.

\section{Materials and Methods}

Animals. We collected adult male Gambel's white-crowned sparrows in eastern Washington during their spring and fall migrations. Birds were group housed in outdoor aviaries for at least 12 weeks before being placed in indoor aviaries. Once inside, birds were exposed to a short day photo-

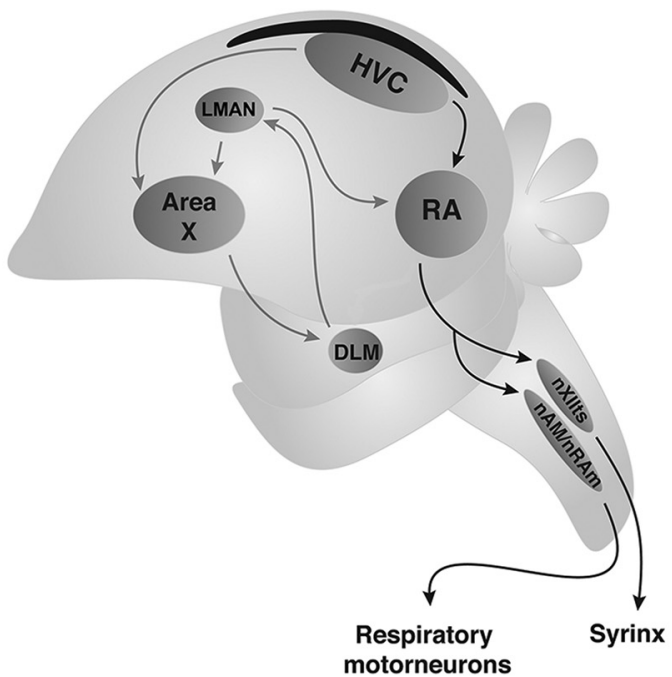

BrdU

Respiratory

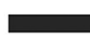

Retrograde Tracer

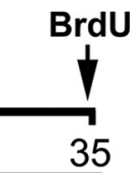

28

$\mathrm{LD}+\mathrm{T}$ or $\mathrm{SD}+\mathrm{BI}$ 35

Figure 1. a, Schematic diagram of the avian song control system. Black arrows indicate the song motor pathway. Gray arrows indicate the anterior forebrain pathway. DLM, Dorsolateral nucleus of the medial thalamus; nAM/nRAm, nucleus ambiguous/nucleus retroambigualis; nXIIts, tracheosyringeal portion of the hypoglossal nucleus. $\boldsymbol{b}$, Timeline of experibefore hormone and photoperiod manipulations, as well as a single BrdU injection $2 \mathrm{~h}$ before death. Retrograde tracer was injected into RA 1 week before death.

period (SD; $8 \mathrm{~h}$ light: $16 \mathrm{~h}$ dark) typical of their wintering grounds for at least 12 weeks before the start of experiments, which ensured that the birds were photosensitive and responsive to hormone manipulations (Tramontin et al., 2000). Food and water were available ad libitum. All procedures were approved by the University of Washington Institutional Animal Care and Use Committee and adhered to National Institutes of Health guidelines.

Experimental design. Experiment 1: We gave acute systemic injections of BrdU to label newborn cells, and injected a $3000 \mathrm{MW}$ dextran retrograde tracer (microruby; Invitrogen D7162) in RA to back-label $\mathrm{HVC}_{\mathrm{RA}}$ projection neurons (Fig. 1b) under breeding and nonbreeding conditions. RA neurons receive inputs from both the lateral magnocellular nucleus of the anterior nidopallium (LMAN) and HVC (Fig. 1a). However, LMAN $_{\mathrm{RA}}$ neurons are not added in adults (Nottebohm, 1985; Alvarez-Buylla et al., 1992); thus, the number of back-filled LMAN neurons is not expected to vary seasonally. The number of $\mathrm{LMAN}_{\mathrm{RA}}$ neurons therefore provides a good control for any seasonal changes of extraneous factors, such as retrograde uptake or transport of tracer, or survival of tracer-labeled neurons (Kirn and Nottebohm, 1993). We also recorded song and analyzed its structure (see below).

Experiment 2: In Experiment 1, we observed that microruby tended not to spread far from the injection site in RA. Kirn and Nottebohm (1993) made a similar observation when they injected latex microspheres into RA. To determine whether the seasonal differences observed in the total number of $\mathrm{HVC}_{\mathrm{RA}}$ neurons, and in the number of newborn $\mathrm{HVC}_{\mathrm{RA}}$ neurons, depended on the specific methods used in Experiment 1, we repeated the study using a different retrograde tracer (Fluorogold; Fluorochrome), as well as a different method of BrdU delivery (continuous release by osmotic pump), and different brain sectioning methods under the same breeding and nonbreeding conditions as Experiment 1.

Labeling new neurons. To mark dividing cells in Experiment 1, we injected birds on SD intramuscularly with bromodeoxyuridine (BrdU, $50 \mathrm{mg} / \mathrm{kg}$ dissolved in $7.5 \% \mathrm{NaCl}$ and $15 \% \mathrm{DMSO}$ ) at the same time 

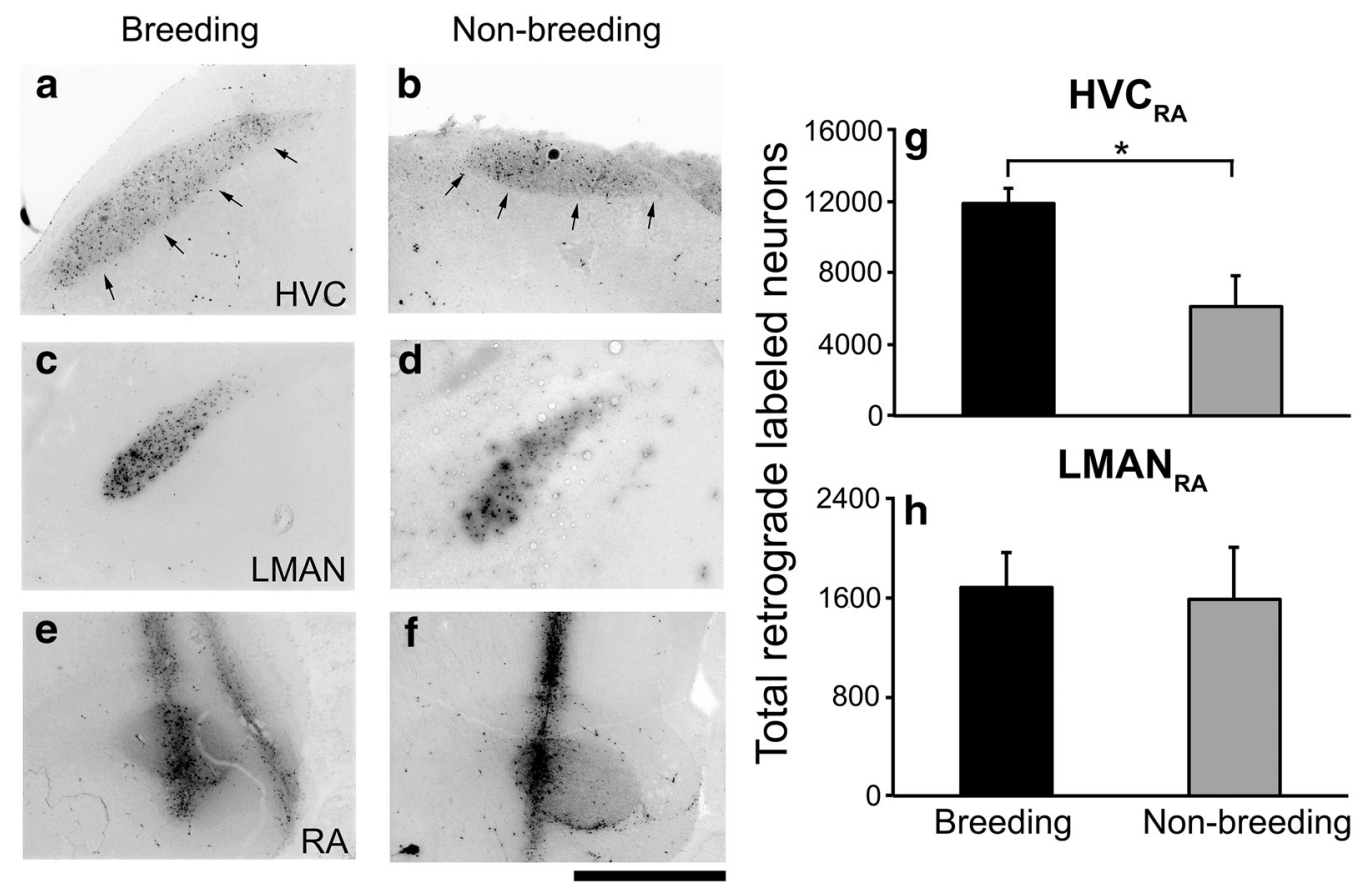

Figure 2. Representative photomicrographs of retrograde labeling (microruby) in $\operatorname{HVC}(\boldsymbol{a}, \boldsymbol{b})$ and $\operatorname{LMAN}(\boldsymbol{c}, \boldsymbol{d})$, and the injection site in $\operatorname{RA}(\boldsymbol{e}, \boldsymbol{f})$. Pictures from a breeding bird are on the left $(\boldsymbol{a}, \boldsymbol{c}, \boldsymbol{e})$ and from a nonbreeding bird in the middle $(\boldsymbol{b}, \boldsymbol{d}, \boldsymbol{f}) \cdot \boldsymbol{a}, \boldsymbol{b}$, Arrows indicate the ventral border of HVC. Scale bar, $1 \mathrm{~mm} . \boldsymbol{g}$, HVC of breeding birds has a greater number of HVC $\mathrm{RA}_{\mathrm{RA}}$ neurons than nonbreeding birds. $\boldsymbol{h}$, There is no difference in the number of $\mathrm{LMAN}_{\mathrm{RA}}$ neurons between breeding conditions. $n=8$ (Breeding; $L D+\mathrm{T}$ ) and 4 (Nonbreeding; $\left.S D+B I\right)$. ${ }^{*} p=0.006$.

relative to "dawn" once per day for $5 \mathrm{~d}$ (acute BrdU administration; Fig. $1 b$ ). In Experiment 2, we labeled dividing cells by infusing BrdU (50 $\mathrm{mg} / \mathrm{kg}$ dissolved in $7.5 \% \mathrm{NaCl}$ and $15 \% \mathrm{DMSO}$ ) for $7 \mathrm{~d}$ via an osmotic pump (Alzet pump 1007D) implanted subcutaneously between the shoulders. All birds began this regimen of BrdU injections or infusions while on SD to ensure that we labeled the cells that would be incorporated into HVC during subsequent photoperiod and hormone treatments (see below). Two hours before death (in the morning), most birds also received a single intraperitoneal injection of $\mathrm{BrdU}$, which labeled proliferating progenitor cells in the ventricular zone (VZ) of the lateral ventricles (Brown et al., 1993).

Breeding condition manipulation. In both Experiments 1 and 2, breeding and nonbreeding conditions were reproduced in a controlled manner in the laboratory by manipulating photoperiod and hormone levels (Smith et al., 1997; Tramontin et al., 2000). To induce breeding-like conditions, birds were housed on a long day photoperiod typical of their arctic breeding grounds ( $20 \mathrm{~h}$ light: $4 \mathrm{~h}$ dark) and given a subcutaneous $\mathrm{T}$ implant (LD $+\mathrm{T}$, breeding) placed between the shoulders. This manipulation produces morphological and physiological changes in the song control nuclei, and increases in song stereotypy, similar to those observed in wild birds (Tramontin et al., 1998; Meitzen et al., 2009). To produce nonbreeding-like conditions, birds were maintained on the same SD photoperiod they were exposed to previously and received an empty implant as a control (SD $+\mathrm{Bl}$, nonbreeding). The implants were constructed from SILASTIC tubing ( $1 \mathrm{~mm}$ inner diameter, $2 \mathrm{~mm}$ outer diameter, $20 \mathrm{~mm}$ length), either filled with $12 \mathrm{~mm}$ of T or left empty, and sealed at the ends with silicone. This treatment produces physiological plasma levels of $\mathrm{T}$ (Tramontin et al., 2003).

Hormone measurements. To measure hormone levels, blood was collected from the alar wing vein of each bird twice: once before hormone pellet implantation and once before death. Blood was collected into heparinized microtainer tubes (BD Biosciences), centrifuged and the plasma was stored at $-20^{\circ} \mathrm{C}$. We measured the concentration of $\mathrm{T}$ in plasma using an enzyme immunoassay kit (Enzo Life Sciences). Samples were run on three different days, and groups were randomly distributed between these days. Each run had an intra-assay coefficient of variation $(\mathrm{CV})$ of $0.076,0.154$, or 0.266 , with an interassay CV of 0.165 between the runs.
Song analysis (Experiment 1 only). One week before surgery, Experiment 1 birds were individually housed in sound isolation chambers (Industrial Acoustics or Coulbourn Instruments). Songs were recorded continuously for $4 \mathrm{~d}$ using Syrinx (J. Burt) or custom-made sound recording software, with sampling parameters described previously (sampling rate was $22050 \mathrm{~Hz}$ ) (Meitzen et al., 2009). Song was also recorded from each bird $24 \mathrm{~h}$ before death. Depending on when the birds sang during these time periods, 20 song files were randomly selected from either the last day the bird sang before surgery (11 LD + T individuals), or the day before death $(1 \mathrm{LD}+\mathrm{T}$ and $2 \mathrm{SD}+\mathrm{Bl}$ individuals) for a total of $12 \mathrm{LD}+\mathrm{T}$ and $2 \mathrm{SD}+\mathrm{Bl}$ birds analyzed. Birds in nonbreeding condition normally sing infrequently in captivity, which accounts for the small sample size for the SD + Bl group (Tramontin et al., 2000; Meitzen et al., 2009). Song files were bandpass filtered from 1.5 to $10 \mathrm{kHz}$. Each syllable (whistle, warble, and buzzes; Fig. $2 a$ ) was extracted from these files. We performed a cross-correlational analysis (i.e., similarity in the energy distribution of two signals) on the spectrograms of whole songs and individual syllables using the batch correlator function in RavenPro 1.4 (Cornell Laboratory of Ornithology) (Larson et al., 2014). Each song or syllable was correlated with other renditions of that same song or syllable from the same bird to determine the percentage of signal similarity across renditions (i.e., stereotypy) for each individual bird. The average percent similarity score was calculated for each syllable and the whole song of all individuals analyzed. We did not analyze the third buzz (Fig. 2a) as birds in both reproductive conditions often omitted this syllable.

Surgery. Following anesthetization with isoflurane (2\%), we made a small incision in the skin overlaying the skull, and a small hole was made in the skull above RA. A glass pipette filled with retrograde tracer $(5 \%$ microruby in saline [Experiment 1] or 0.5\% Fluorogold in water [Experiment 2]) (Kirn and Nottebohm, 1993; Reiner et al., 2000) was lowered bilaterally into RA using the intersection of the midsagittal and transverse sinuses as the reference point (anterior/posterior, $-1.25 \mathrm{~mm}$; medial/ lateral, \pm 2.65 and $2.55 \mathrm{~mm}$; depth, 2.35 and $2.45 \mathrm{~mm}$ ). Approximately $110 \mathrm{nl}$ of tracer was pressure injected at each of the four sites using a customized pressure delivery system. All injections were performed blind to the bird's treatment. One week following retrograde tracer injection, animals were deeply anesthetized and perfused with saline followed by 
$4 \%$ PFA. Brains were collected, postfixed in 4\% PFA, soaked in sucrose, and stored at $-20^{\circ} \mathrm{C}$ until processing.

Tissue was sectioned coronally at $40 \mu \mathrm{m}$ on a cryostat into six series and thaw-mounted onto gelatin-coated slides (Experiment 1). Slides were stored at $-20^{\circ} \mathrm{C}$ until further processing. Tissue from Experiment 2 was sectioned at $40 \mu \mathrm{m}$ on a freezing microtome and stored in saline at $4^{\circ} \mathrm{C}$ until further use. All sections were collected for both experiments.

Immunohistochemistry. We performed immunohistochemistry (IHC) for BrdU on one series (every sixth section) and an IHC for both BrdU and neuron-specific marker (NeuN) on another series. For Experiment 1, IHC was conducted on slide-mounted sections. For Experiment 2, IHC was conducted on free-floating sections that were mounted on slides after the procedure. We rinsed tissue in $0.5 \%$ Triton $\mathrm{X}$ and $0.5 \%$ DMSO in $0.1 \mathrm{M} \mathrm{PBS} \mathrm{(PDTX)} \mathrm{and} \mathrm{treated} \mathrm{with} 2 \mathrm{M} \mathrm{HCl}$ at $37^{\circ} \mathrm{C}$ for $30 \mathrm{~min}$. Tissue was rinsed with $0.1 \mathrm{~m}$ boric acid, $\mathrm{pH} 8.5$, followed by PDTX. We blocked with 5\% normal goat serum (NGS) for $1 \mathrm{~h}$ and incubated overnight at $4^{\circ} \mathrm{C}$ with primary antibodies (BrdU, $5 \mu \mathrm{g} / \mathrm{ml}$, rat IgG, AbD Serotec, \#MCA2060GA; NeuN, $2 \mu \mathrm{g} / \mathrm{ml}$, mouse IgG, Millipore Bioscience Research Reagents, \#MAB377) in NGS. Tissue was rinsed in PDTX and incubated with secondary antibodies $(7.5 \mu \mathrm{g} / \mathrm{ml}, 488$ goat anti-rat IgG \#A11006, 568 goat anti-mouse IgG \#A11004; Invitrogen) in $0.1 \mathrm{M}$ PBS for $2 \mathrm{~h}$ at room temperature. Tissue was rinsed in PBS and coverslipped with $10 \% 0.1 \mathrm{M}$ Tris buffer, $\mathrm{pH} 9.0$, and $5 \mathrm{mg} / \mathrm{ml} n$-propyl gallate in glycerol.

Cell counts. For both Experiments 1 and 2, every third section containing HVC ( 8 sections per hemisphere on average) or LMAN (3 sections per hemisphere on average) was examined for retrogradely labeled cells. We confirmed that tracer was present within the borders of RA and retrogradely labeled neurons were present in HVC and LMAN. We counted labeled neurons throughout HVC and LMAN. Axons of individual HVC neurons branch widely in different regions of RA (i.e., are not topographical), whereas individual LMAN neurons do have topographical projections to RA (Johnson et al., 1995; Yip et al., 2012). Labeled cells were therefore sampled throughout the full extent of HVC, but only in the sections of LMAN that contained tracer. To determine the density of backfilled neurons, four boxes (each $125 \mu \mathrm{m}^{2}$ ) were randomly placed in each sampled section of HVC or LMAN and all labeled cells were counted. Following these counts, the coverslips were removed and the same sections were Nissl-stained. HVC, LMAN, and RA volumes were calculated by tracing the borders of each nucleus as defined by Nissl staining (Tramontin et al., 1998) and volumes from both hemispheres of each nucleus were summed. The number of projection neurons was estimated by multiplying the density by the entire volume of HVC, or the volume of LMAN that contained retrogradely labeled cells, for each bird individually.

To ensure that tracer injections in RA were taken up and retrogradely transported by neurons throughout the full extent of $\mathrm{HVC}$, we also determined $\mathrm{HVC}$ volume based on the distribution of labeled $\mathrm{HVC}_{\mathrm{RA}}$ neurons. HVC volumes from both Nissl and retrograde tracer were compared using paired $t$ tests for each treatment separately and combined. There was no difference between HVC volume as defined by Nissl or retrograde tracer in Experiment 1 (breeding only: $t=0.36, p=0.741$; nonbreeding only: $t=0.68, p=0.544$; both: $t=0.095, p=0.927$ ) or Experiment 2 (breeding only: $t=0.21, p=0.849$; nonbreeding only: $t=$ $1.72, p=0.228$; both: $t=1.28, p=0.247$ ). These results show that both microruby and Fluorogold injections in RA successfully labeled RAprojecting neurons distributed throughout HVC.

All new neurons (cells that colabeled for BrdU and NeuN), and new $\mathrm{HVC}_{\mathrm{RA}}$ projection neurons (cells colabeled for BrdU and tracer), were counted throughout HVC on every sixth section (4 sections per hemisphere on average). We also counted the number of BrdU-positive cells that were not colabeled with either tracer or NeuN, presumably glial or ependymal cells.

To determine the rate of proliferation of progenitor cells in the VZ, BrdU-positive cells were counted in all sections that exhibited arching of the VZ (Scott and Lois, 2007; Larson et al., 2014). New HVC neurons are born in this region of the VZ (Scott et al., 2012). BrdU-positive cells were only counted when they were on the ventral side of the ventricle, adjacent to HVC (12 sections per hemisphere on average).
Table 1. Testosterone levels and brain morphology across treatments ${ }^{a}$

\begin{tabular}{lcc}
\hline & $\begin{array}{l}\text { Breeding condition } \\
(\mathrm{LD}+\mathrm{T})\end{array}$ & $\begin{array}{l}\text { Nonbreeding condition } \\
(\mathrm{SD}+\mathrm{BI})\end{array}$ \\
\hline $\begin{array}{l}\text { T levels (ng/ml) } \\
\quad \text { Pre }\end{array}$ & $0.42 \pm 0.13$ & $0.36 \pm 0.11$ \\
$\quad$ Post & $17.57 \pm 2.38^{*}$ & $0.22 \pm 0.07^{*}$ \\
HVC volume $\left(\mathrm{mm}^{3}\right)$ & & \\
$\quad$ Experiment 1 & $0.70 \pm 0.03^{*}$ & $0.53 \pm 0.05^{*}$ \\
$\quad$ Experiment 2 & $2.12 \pm 0.14^{*}$ & $1.10 \pm 0.09^{*}$ \\
RA volume $\left(\mathrm{mm}^{3}\right)$ & & \\
$\quad$ Experiment 1 & $0.30 \pm 0.02^{*}$ & $0.21 \pm 0.01^{*}$ \\
BrdU-positive cell no. in HVC & & \\
$\quad$ Experiment 1 & $463 \pm 95$ & $535 \pm 158$ \\
$\quad$ Experiment 2 & $797 \pm 449$ & $65 \pm 27$ \\
BrdU-positive cell no. in VZ & & \\
$\quad$ Experiment 1 & $2034 \pm 129$ & $1890 \pm 287$ \\
HVC & & \\
$\quad$ RA density $\left(\times 10^{2}\right.$ cells $\left./ \mathrm{mm}^{3}\right)$ & $173.22 \pm 8.54^{*}$ & $100.74 \pm 27.41^{*}$ \\
$\quad$ Experiment 1 & $504.61 \pm 44.63$ & $592.01 \pm 81.05$ \\
\hline
\end{tabular}

${ }^{a}$ Data are mean \pm SEM. BrdU-positive cells are cells that did not colabel with other markers.

*Treatment groups differ significantly ( $p \leq 0.008, t$ test).

Statistics. After performing Levene's test for variance equality, we used independent $t$ tests to determine whether there were differences between breeding and nonbreeding birds in Experiments 1 and 2 (SPSS Statistics, IBM). If the Levene's test revealed that the data did not meet the assumptions of the independent $t$ test, the data were log-transformed before further statistical analysis (Kempermann et al., 2006). Pearson's correlations were used to determine whether there was a relationship between retrograde labeling in LMAN and HVC, as well as whether there was a relationship between the number of new neurons (total and retrogradely labeled) and song stereotypy or between the number of new neurons (total and retrogradely labeled) and T levels (Experiment 1 only). Final sample sizes are indicated in the figure legends, and all values reported are mean \pm SEM. Cohen's $d$ was used to calculate effect size ( $d$ values $>0.8$ indicate large effects) (Cohen, 1988).

\section{Results}

\section{Confirmation of breeding condition}

Our hormone and photoperiod manipulations were effective in inducing physiological and behavioral states typical of breeding $(\mathrm{LD}+\mathrm{T})$ and nonbreeding $(\mathrm{SD}+\mathrm{Bl})$ condition birds in both experiments.

Before hormone and photoperiod manipulation, there was no difference in plasma $\mathrm{T}$ concentration between animals in Experiments 1 and 2 that were later used in $\mathrm{LD}+\mathrm{T}$ or $\mathrm{SD}+\mathrm{Bl}$ conditions $\left(t_{(28)}=0.27, p=0.789, d=0.30\right.$; Table 1$)$. At the time of death, birds exposed to LD $+\mathrm{T}$ had significantly higher T levels than those exposed to $\mathrm{SD}+\mathrm{Bl}\left(t_{(17.03)}=7.28, p<0.001, d=3.53\right)$.

Changes in HVC volume and neuronal number, and in behavioral song stereotypy, described below, also confirm the effectiveness of the hormonal and photoperiod manipulations.

\section{Experiment 1}

In Experiment 1, mean HVC volume was greater in birds in breeding compared with nonbreeding condition $\left(t_{(19)}=3.04\right.$, $p=0.007, d=1.39$; Table 1$)$. RA volume was also larger in breeding compared with nonbreeding individuals $\left(t_{(11)}=3.85\right.$, $p=0.003, d=2.32$ ).

\section{Breeding birds had more $\mathrm{HVC}_{\mathrm{RA}}$ neurons (Experiment 1)}

To quantify the number of HVC neurons that project to RA in breeding and nonbreeding conditions, we injected the retrograde tracer microruby into RA and counted the number of cells that were labeled in $\mathrm{HVC}$ ( $\mathrm{HVC}_{\mathrm{RA}}$ neurons). The number of retro- 
New HVC neurons
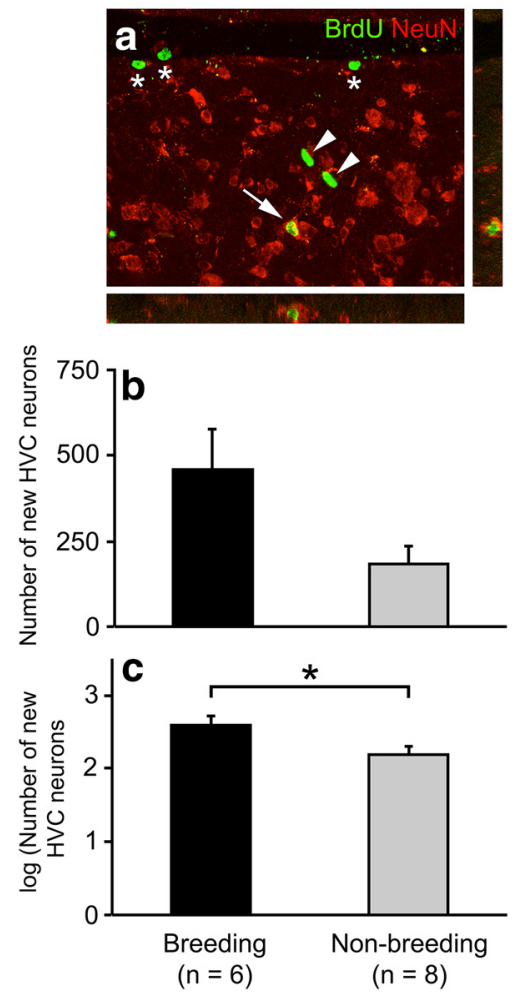

New $\mathrm{HVC}_{\mathrm{RA}}$ neurons
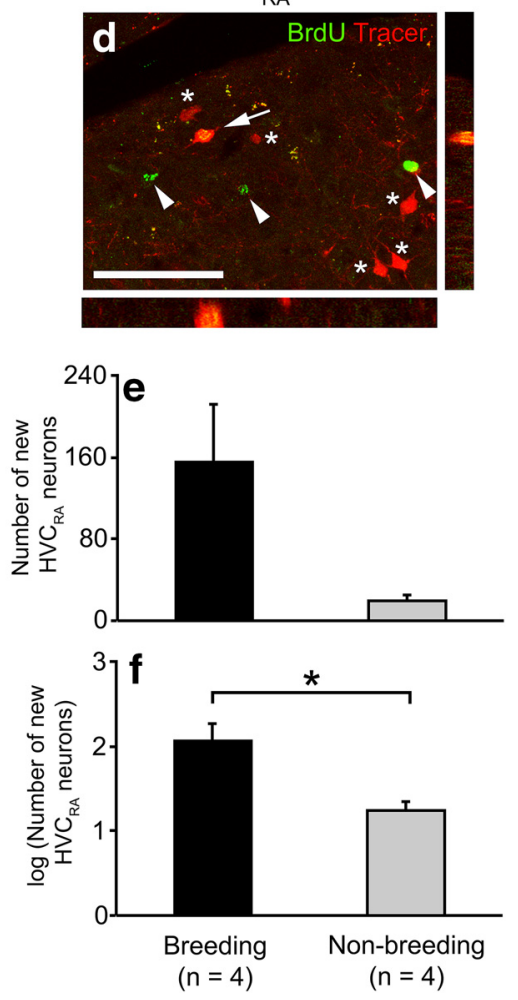

Figure 3. Neuronal addition to $\mathrm{HVC}(\boldsymbol{a}-\boldsymbol{c})$ and $\mathrm{HVC}_{\mathrm{RA}}$ projection neuron addition $(\boldsymbol{d}-\boldsymbol{f})$ is higher in breeding than nonbreeding birds. $\boldsymbol{a}$, Cells labeled for NeuN (red) and BrdU (green). Arrow indicates a new HVC neuron that was double-labeled and is shown in $x z$ and $y z$ planes. Arrowheads indicate BrdU-positive cells that did not label for NeuN. Asterisks indicate BrdU-positive cells in the ventricular zone. $\boldsymbol{b}$, Raw data of the number of new neurons in HVC. $\boldsymbol{c}$, Log transformations revealed that there were significantly more new HVC neurons in breeding than nonbreeding birds ( $n=6$ breeding and 8 nonbreeding). $\boldsymbol{d}$, Labeling for retrograde tracer (microruby; red) and BrdU (green). Arrow indicates a new $\mathrm{HVC}_{\mathrm{RA}}$ projection neuron that was double-labeled, shown in $X Z$ and $Y Z$ planes. Arrowheads indicate BrdU-positive cells that were not projection neurons. Asterisks indicate $H V C_{R A}$ neurons that were not BrdU-positive. $\boldsymbol{e}$, Raw data of the number of new $\mathrm{HVC}_{\mathrm{RA}}$ projection neurons. $\boldsymbol{f}$, Log transformations revealed that there were significantly more new $\mathrm{HVC}_{\mathrm{RA}}$ neurons $(n=4)$ in breeding compared with nonbreeding birds. Scale bars: $\boldsymbol{a}, \boldsymbol{d}, 100 \mu \mathrm{m} . \boldsymbol{c}, \boldsymbol{f}^{*}{ }^{*} p<$ 0.05 .

gradely labeled neurons in HVC was greater in breeding compared with nonbreeding birds, with $49 \%$ fewer RA-projecting neurons in nonbreeding birds (Fig. $2 a, b, g ; t_{(10)}=3.47, p=0.006$, $d=2.20)$. $\mathrm{HVC}_{\mathrm{RA}}$ neuron density was also greater in breeding compared with nonbreeding birds (Table $1 ; t_{(10)}=3.27, p=$ $0.008, d=2.07)$.

To determine whether there was a difference between treatment groups in either the injection of tracer or its retrograde transport, the number of retrogradely labeled neurons was also measured in the song nucleus LMAN. LMAN projects to RA but does not add new RA-projecting neurons in adulthood (Kirn and Nottebohm, 1993). There was no effect of reproductive condition on the number of labeled $\mathrm{LMAN}_{\mathrm{RA}}$ neurons (Fig. $2 c, d, h ; t_{(10)}=$ $0.66, p=0.523, d=0.42)$ or density $\left(t_{(10)}=0.98, p=0.351, d=\right.$ $0.62)$. We tested whether the number of labeled neurons in LMAN was related to the number of labeled neurons in HVC for all Experiment 1 animals using a Pearson's correlation. There was no correlation between these two variables for each breeding condition analyzed separately $\left(r_{(8,4)}^{2} \leq 0.77, p \geq 0.123\right)$, or combined $\left(r_{(12)}^{2}=0.04, p=0.561\right)$, indicating that there was no relationship between the numbers of retrogradely labeled $\mathrm{HVC}_{\mathrm{RA}}$ and $\mathrm{LMAN}_{\mathrm{RA}}$ neurons. Together, these data suggest that there was no systematic difference between treatment groups in the retrograde transport of tracer from RA to afferent HVC neurons.

Breeding birds had more new neurons in HVC (Experiment 1)

To quantify the number and type of new adult-born neurons, we counted the cells that were labeled for BrdU (a marker of cell division), NeuN (a neuron-specific marker), and/or retrograde tracer (an $\mathrm{HVC}_{\mathrm{RA}}$ neuron). We quantified the numbers of new HVC neurons (BrdU + NeuN), new $\mathrm{HVC}_{\mathrm{RA}}$ neurons (BrdU + tracer), and new non-neuronal HVC and VZ cells (BrdU only).

We found that there were more new HVC neurons in birds in breeding compared with nonbreeding conditions (Fig. $3 a-c ; t_{(12)}=2.57, p=0.025, d=$ 1.48). We also detected more new HV$\mathrm{C}_{\mathrm{RA}}$ neurons in breeding compared with nonbreeding birds (Fig. $3 d-f ; t_{(6)}=$ $3.48, p=0.013, d=2.84)$. The number of new non-neuronal cells in HVC $\left(t_{(12)}=0.38, p=0.708, d=0.22\right.$; Table $1)$ or $\mathrm{VZ}\left(t_{(12)}=0.62, p=0.547, d=\right.$ 0.36) did not differ between breeding and nonbreeding condition birds.

\section{Song stereotypy correlated with new HVC $_{\text {RA }}$ neurons (Experiment 1)}

We used cross-correlational analysis for individual song and syllable files to determine the similarity of each syllable or the entire song across renditions for each bird. Whole song had a higher percent similarity in breeding than nonbreeding birds $\left(t_{(10)}=4.42, p=0.001, d=2.80\right.$; Fig. 4). Analysis of individual syllables revealed that each syllable also had a higher percent similarity in breeding than nonbreeding individuals (all $t \geq 3.07, p \leq$ $0.012, d \geq 1.942$ ). These behavioral results further confirm that the two treatment groups differed in physiological condition and are similar to previous work examining song stereotypy in whitecrowned sparrows (Meitzen et al., 2009; Larson et al., 2014).

We performed a Pearson's correlation analysis to examine the relationship between new neurons and song stereotypy. Interestingly, we found that there was a strongly positive correlation between whole song stereotypy (from cross-correlations) and the number of new $\mathrm{HVC}_{\mathrm{RA}}$ neurons $\left(r_{(5)}^{2}=0.98, p=0.001\right.$; Fig. $\left.5 a\right)$. This relationship was also true for whistle percent similarity $\left(r_{(5)}^{2}=0.996, p<0.001\right.$; Fig. $\left.5 c\right)$ and warble percent similarity $\left(r_{(5)}^{2}=0.83, p=0.032\right.$; Fig. $\left.5 e\right)$. There was no relationship between the number of new $\mathrm{HVC}_{\mathrm{RA}}$ neurons and other syllables $\left(r_{(5)}^{2} \leq 0.69, p \geq 0.082\right.$; data not shown), or the total number of new neurons $(\mathrm{BrdU}+\mathrm{NeuN})$ with any measure of song quality $\left(r_{(6)}^{2} \leq 0.58, p \geq 0.078\right.$; Fig. 5b,d,f). We also did not detect a correlation between the total number of retrogradely labeled HV$\mathrm{C}_{\mathrm{RA}}$ neurons and song stereotypy (all $r_{(9)}^{2}$ or $r_{(8)}^{2} \leq 0.37, p \geq 0.108$; data not shown).

Hormone levels correlated with new neurons (Experiment 1) We performed a Pearson's correlation analysis to examine the relationship between $\mathrm{T}$ levels and neurogenesis. We found that there was a positive relationship between circulating $\mathrm{T}$ levels at 
the time of death and both the number of new $\mathrm{HVC}_{\mathrm{RA}}$ neurons $\left(r_{(8)}^{2}=0.75, p=\right.$ 0.005 ; Fig. $5 g$ ) and the total number of new HVC neurons $\left(r_{(13)}^{2}=0.41, p=\right.$ 0.018; Fig. 5h). There was no relationship between $\mathrm{T}$ levels and the number of new non-neuronal cells in HVC or VZ (all $\left.r_{(13)}^{2} \leq 0.09, p \geq 0.325\right)$.

\section{Experiment 2}

As in Experiment 1, we found that breeding condition birds had a larger HVC volume than nonbreeding birds $\left(t_{(8)}=6.027\right.$, $p<0.001, d=4.26$; Table 1$)$, and these volumes were similar to those observed in previous studies (Larson et al., 2014). The results of Experiments 1 and 2 agree in showing that HVC increased in size in breeding condition birds, defined either by Nissl staining or the distribution of labeled $\mathrm{HVC}_{\mathrm{RA}}$ neurons.

Experiment 2 used a chronic BrdU infusion to label new cells, a different retrograde tracer (Fluorogold), and different tissue processing methods (IHC on freefloating freezing microtome sections) in a different set of birds. The results from this experiment confirmed those from Experiment 1. Similar results were observed, such that there were $36 \%$ more $\mathrm{HVC}_{\mathrm{RA}}$ neurons in breeding than nonbreeding individuals $\left(t_{(8)}=2.66, p=0.029, d=1.88\right.$; Fig. $6 a, d, i)$, although there was no difference in $\mathrm{HVC}_{\mathrm{RA}}$ neuron density (Table 1; $\left.t_{(8)}=0.95, p=0.373, d=0.67\right)$. We did not find a difference between conditions in $\mathrm{LMAN}_{\mathrm{RA}}$ neuron number $\left(t_{(8)}=0.07\right.$, $p=0.947, d=0.05$; Fig. $6 b, e, j)$ or density $\left(t_{(8)}=0.31, p=0.767, d=0.22\right)$. We observed more new neurons in HVC (logtransformed: $t_{(8)}=3.92, p=0.004, d=$ 2.77; Fig. $6 g, k, l$ ) and more new $\mathrm{HVC}_{\mathrm{RA}}$ neurons (log-transformed: $t_{(7)}=3.13, p=0.017, d=2.36$; Fig. $6 h, m, n$ ) in breeding compared with nonbreeding individuals. There was no difference in new non-neuronal HVC cells between treatment groups $\left(t_{(8)}\right.$ $=1.63, p=0.142, d=1.03$; Table 1).

We examined whether there was a relationship between circulating T levels and neurogenesis in Experiment 2 using a Pearson's correlation analysis. Similar to Experiment 1, we found a positive correlation between circulating $\mathrm{T}$ levels at the time of death and the number of new HVC neurons (log-transformed; $\left.r_{(10)}^{2}=0.55, p=0.014\right)$. Additionally, we did not detect a correlation between $\mathrm{T}$ levels and the number of new non-neuronal HVC cells $\left(r_{(10)}^{2}=0.08, p=0.436\right)$. The correlation between $\mathrm{T}$ levels and new $\mathrm{HVC}_{\mathrm{RA}}$ neurons approached significance (logtransformed; $\left.r_{(9)}^{2}=0.43, p=0.055\right)$.

We found that Fluorogold spread considerably further from the injection site in $\mathrm{RA}$ and labeled more $\mathrm{HVC}_{\mathrm{RA}}$ neurons than did microruby. The differential spread of these tracers, however, did not alter any of the fundamental results of our study. Breeding birds had larger HVC as defined by tracer labeling, and a greater number of both newborn and total HVC-RA neurons than did nonbreeding
Non-breeding

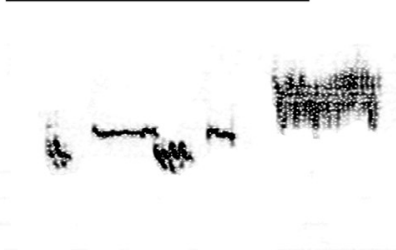

Birds in breeding condition sing more stereotyped song than those in nonbreeding condition. $\boldsymbol{a}$, Three song exempird in breeding condition (left) and a different bird in nonbreeding condition (right). $\boldsymbol{b}$, The percent similarity between different renditions of whole song and individual syllables for breeding and nonbreeding individuals. The terminal buzz is sometimes omitted from song and therefore was not included in analysis. ${ }^{*} p<0.05 . n=10(\mathrm{LD}+\mathrm{T})$ and 2 (SD $+\mathrm{BI}$ ). Some birds in nonbreeding condition do not sing in isolation from other birds, which accounts for the small sample size in that group.

birds, regardless of the tracer injected in RA. Replication of these results using different tracers, different ways of delivering BrdU, and different tissue processing methods for IHC increases confidence in the results.

\section{Effect sizes}

In both Experiments 1 and 2, the magnitude of the differences between breeding and nonbreeding condition birds in the numbers of new HVC and new $\mathrm{HVC}_{\mathrm{RA}}$ neurons, and the number of all $\mathrm{HVC}_{\mathrm{RA}}$ neurons, is quite large. The Cohen's $d$ values for all statistically significant comparisons are $>1.48$. As a reference, a $d$ value of 1.5 indicates that the mean values for breeding birds are $>93 \%$ of the values for nonbreeding birds (Sullivan and Feinn, 2012). This analysis indicates that the seasonal change in the HVC-RA circuit is a robust phenomenon.

\section{Discussion}

The birth of new neurons and their integration into circuits in the adult brain has been the focus of intensive research. The functional significance of adult neurogenesis, however, continues to be unclear. Here, we demonstrate that new neurons contribute to the regeneration of a telencephalic long-range neural circuit in 


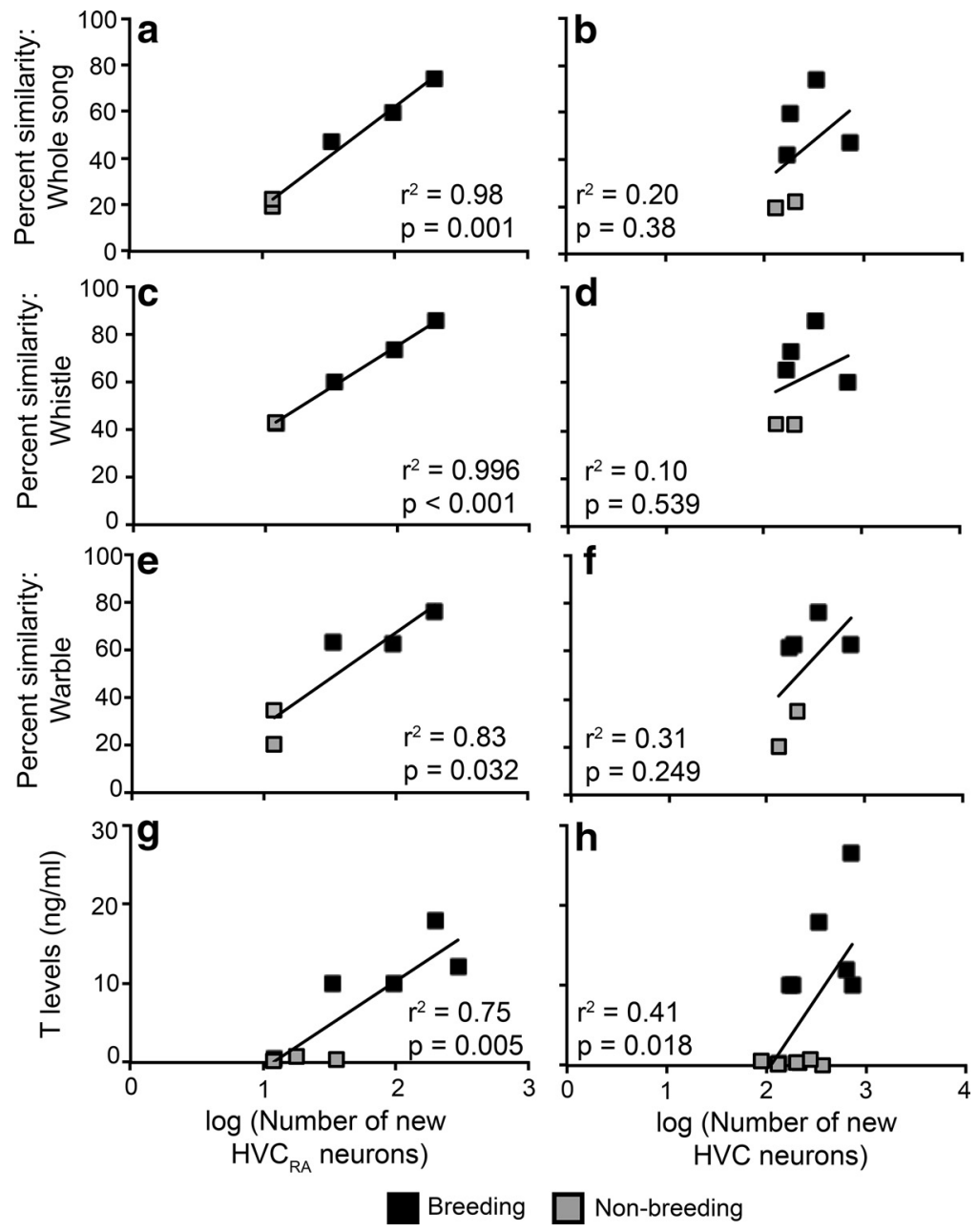

Figure 5. The integration of new projection neurons to HVC is correlated with song quality and T levels. The number of new $\mathrm{HVC}_{\mathrm{RA}}$ neurons is correlated with the percent similarities of whole song $(\boldsymbol{a})$, whistle $(\boldsymbol{c})$, and warble $(\boldsymbol{e})$, and is also correlated with circulating T levels $(\boldsymbol{g})$. The total number of new HVC neurons did not correlate with song measures $(\boldsymbol{b}, \boldsymbol{d}, \boldsymbol{f})$ but is correlated with T levels (h). Log-transformed data were used for correlational analysis.

adult songbirds, and this leads to improved performance of learned song.

\section{Plasticity of a neural circuit in an adult brain}

We found that the premotor HVC-RA circuit in the song system of adult white-crowned sparrows is seasonally degraded and reconstructed. As many as $46 \%$ of HVC neurons that project to RA die in nonbreeding birds due to caspasedependent apoptosis (Thompson and Brenowitz, 2008) (Fig. 7). In breeding birds, this circuit is regenerated as newborn neurons are added to HVC and grow axons to innervate RA neurons. These seasonal changes in the number of $\mathrm{HVC}_{\mathrm{RA}}$ neurons are correlated with changes in circulating $\mathrm{T}$ levels and with changes in song duration and stereotypy.

Our results agree with previous research in adult male canaries (Serinus canaria), which showed that $\mathrm{HVC}_{\mathrm{RA}}$ projection neurons are replaced over time (Kirn et al., 1991; Kirn and Nottebohm, 1993). Sparrows differ from canaries, however, in the extent and seasonal timing of turnover in $\mathrm{HVC}_{\mathrm{RA}}$ neurons. Kirn et al. (1991) reported that there were no seasonal differences in the volume of $\mathrm{HVC}$, the number or proportion of $\mathrm{HVC}_{\mathrm{RA}}$ neurons, or the total number of HVC neurons in canaries. Other studies reported a small, transient reduction in HVC volume in early fall, and that the density of newborn HVC neurons, and the density and percent of newborn $\mathrm{HVC}_{\mathrm{RA}}$ neurons, were somewhat greater in the fall in canaries (Alvarez-Buylla et al., 1990; Nottebohm et al., 1994). By contrast, we found that the number of all HVC neurons, newborn HVC neurons, all $\mathrm{HVC}_{\mathrm{RA}}$ projection neurons, and newborn $\mathrm{HVC}_{\mathrm{RA}}$ projection neurons were greater in breeding white-crowned sparrows than nonbreeding birds. The effect sizes for all comparisons in sparrows are large, showing that the seasonal changes in the HVC-RA circuit are robust in this species. It is not clear why canaries and sparrows differ; this may reflect adult song learning in canaries but not sparrows, or more pronounced reproductive seasonality in the arctic breeding sparrows than in the subtropical canaries (Bentley et al., 2003; Leitner et al., 2003).

An alternative explanation of our results might be that seasonal change in $\mathrm{HVC}_{\mathrm{RA}}$ neurons was not due to seasonal loss and replacement of these neurons but to axon retraction (Luo and O'Leary, 2005) and regrowth. Several observations are inconsistent with this scenario. First, many $\mathrm{HVC}_{\mathrm{RA}}$ neurons in breeding birds are labeled by BrdU and therefore likely newborn. Second, the decrease in $\mathrm{HVC}_{\mathrm{RA}}$ neurons we observed is consistent with previous measurements showing that total HVC neuron number rapidly decreases by $40 \%$ in nonbreeding birds (Tramontin et al., 1998; Thompson et al., 2007; Larson et al., 2014). Third, the heavily myelinated HVC-RA fiber tract is visible under polarized light in unfixed tissue from nonbreeding sparrows, albeit of reduced size (E.A.B., unpublished observation). Together, these observations indicate that seasonal changes in the number of tracer-labeled $\mathrm{HVC}_{\mathrm{RA}}$ neurons result from the death and replacement of projection neurons. Further support for this conclusion is the lack of seasonal change in the number of $\mathrm{LMAN}_{\mathrm{RA}}$ neurons, which suggests that our results cannot be explained by changes in the uptake or transport of the tracer injected in RA (see also Kirn and Nottebohm, 1993).

Previous research has shown that most, if not all, new HVC neurons project to RA (Kirn et al., 1991; Scott and Lois, 2007; Scotto-Lomassese et al., 2007). Not all new HVC neurons in our study were backfilled with tracer, similar to previous work showing that only approximately half of new HVC neurons were labeled by tracer injected in RA of adult zebra finches (Taeniopygia guttata) (Walton et al., 2012). One possible explanation for unlabeled new neurons is that 4 weeks after BrdU injection may not be long enough for all new neurons to grow axons to RA. Research in canaries showed an increase in the number of new retrogradely labeled HVC neurons over $240 \mathrm{~d}$ after birth (Kirn et al., 1991), suggesting that some new HVC neurons require $>4$ weeks to synapse on RA neurons. It is also possible that some new HVC neurons that were not labeled could be interneurons (e.g., Scott and Lois, 2007). 

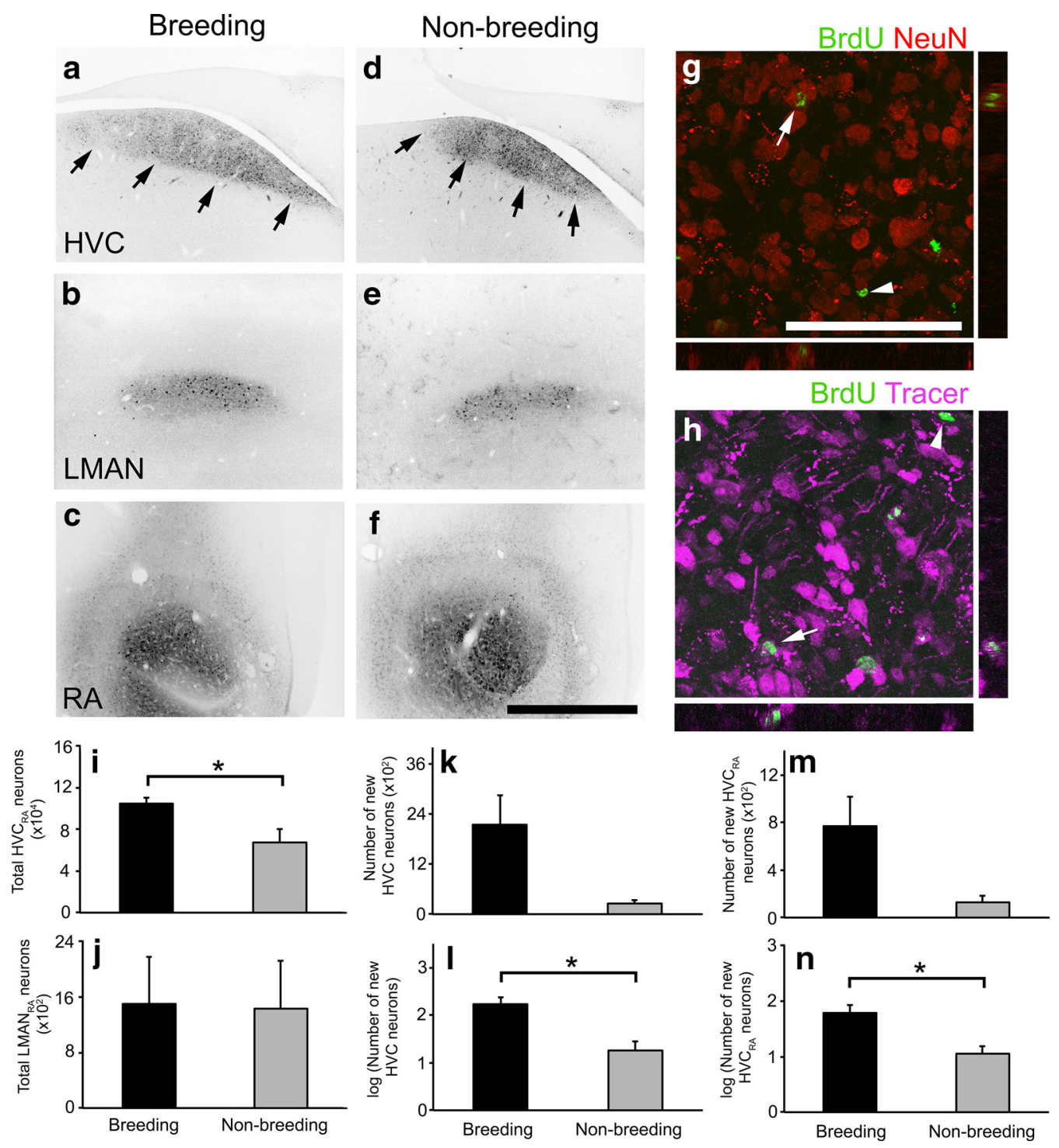

Figure 6. Results from Experiment 1 were confirmed using a chronic BrdU infusion with an osmotic pump and a different retrograde tracer (Fluorogold) in Experiment 2. Representative photomicrographs are shown of retrograde labeling in $\operatorname{HVC}(\boldsymbol{a}, \boldsymbol{d})$ and $\operatorname{LMAN}(\boldsymbol{b}, \boldsymbol{e})$, as well as the injection site in RA $(\boldsymbol{c}, \boldsymbol{f})$. Pictures from a breeding bird are on the left $(\boldsymbol{a}-\boldsymbol{c})$ and from a nonbreeding bird in the middle $(\boldsymbol{d}-\boldsymbol{f}) . \boldsymbol{a}, \boldsymbol{d}$, Arrows indicate the ventral border of HVC. Scale bar, $1 \mathrm{~mm}$. Representative photomicrographs of $(\boldsymbol{g})$ new neurons (NeuN, red and BrdU, green) and of $(\boldsymbol{h})$ new retrogradely labeled neurons (Fluorogold, magenta and BrdU, green). $\boldsymbol{g}, \boldsymbol{h}$, Arrows indicate a double-labeled cell that is shown in the XZ and $Y Z$ plane. Arrowheads indicate a BrdU-positive cell that did not label for NeuN $(\boldsymbol{g})$ or tracer $(\boldsymbol{h})$. Scale bars: $\boldsymbol{g}, \boldsymbol{h}, 100 \mu \mathrm{m}$. $\boldsymbol{i}$, There were more $\mathrm{HVC}_{\mathrm{RA}}$ neurons in birds in breeding compared with nonbreeding conditions, with no effect on the number of $\mathrm{LMAN}_{\mathrm{RA}}$ neurons across conditions $(\boldsymbol{j})$. There were more new HVC neurons $(\boldsymbol{k}, \boldsymbol{I})$ and new $\mathrm{HVC}_{\mathrm{RA}}$ neurons $(\boldsymbol{m}, \boldsymbol{n})$ in breeding compared with nonbreeding conditions. $\boldsymbol{k}, \boldsymbol{m}$, Raw data. $\boldsymbol{l}, \boldsymbol{n}$, Log-transformed data. $n=5 .{ }^{*} p<0.05$.

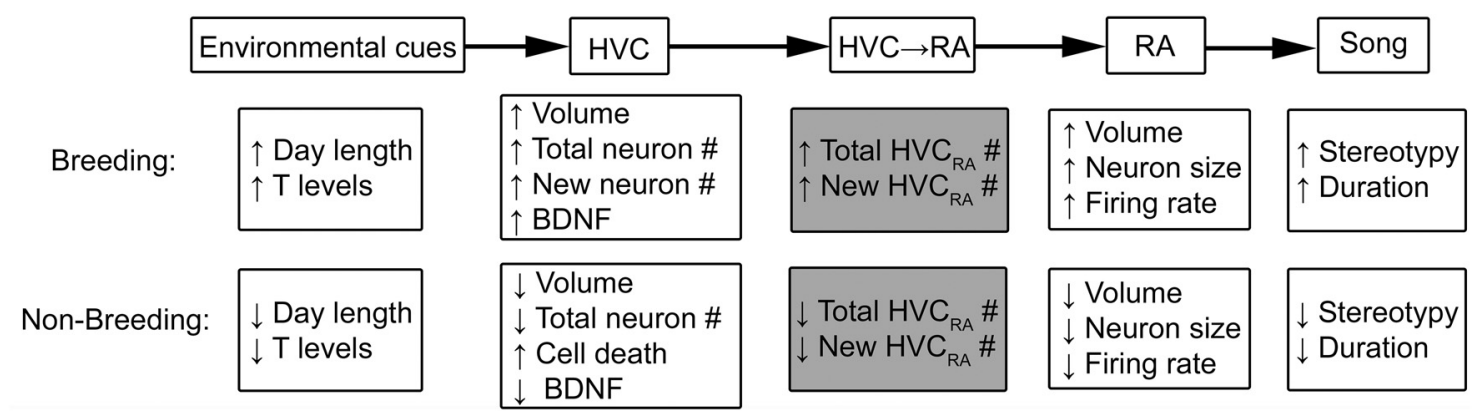

Figure 7. Summary of seasonal changes in the adult white-crowned sparrow song system. As day length increases early in the breeding season, testosterone ( $T$ ) levels increase. T upregulates expression of BDNF mRNA in HVC cells. T and BDNF increase the survival of new neurons, and total neuron number and volume of HVC increase. Here we demonstrate that many of these new neurons send axons to RA and the HVC-RA circuit is reconstructed. The size and activity of neurons in RA increase, and song becomes more stereotyped. In the nonbreeding season, T concentration drops to basal levels, BDNF expression is silenced, and mature and newborn HVC neurons, including many that project to RA, die from the loss of trophic support. The HVC-RA circuit degrades, electrical activity and size of RA neurons decrease, and song becomes less stereotyped. Shaded boxes represent new information from the current study. 
It is interesting that the HVC-RA circuit was not completely eliminated when it degenerated in nonbreeding birds. Approximately half of $\mathrm{HVC}_{\mathrm{RA}}$ neurons persisted in the degraded circuit. It may be that adult-born HVC neurons can only grow axons to RA by following existing pathways, as shown for adult-born neurons in the mammalian olfactory system (Ma et al., 2014). On a functional level, wild white-crowned sparrows sing in the fall and winter, albeit with less stereotypy and less often. They forage in flocks during the day and roost communally at night, and song may play a role in social cohesion in these contexts (Brenowitz, 1981). Without some remaining connectivity between HVC and RA, nonbreeding birds would not be able to sing (Brainard and Doupe, 2013).

\section{Circuit reconstruction and song behavior}

We confirmed that breeding song was more stereotyped than nonbreeding song (see also Smith et al., 1995; Meitzen et al., 2009). The degree of stereotypy, measured as the cross-correlation coefficient, was highly correlated with the number of new $\mathrm{HVC}_{\mathrm{RA}}$ neurons. The introductory whistle is the dominant cue for learning and recognizing conspecific song in white-crowned sparrows (Soha and Marler, 2000; Nelson, 2007), and its stereotypy was strongly correlated with new $\mathrm{HVC}_{\mathrm{RA}}$ neuron number. These high correlations suggest that integration of newborn $\mathrm{HVC}_{\mathrm{RA}}$ neurons to reconstruct the circuit enables males to produce high-quality songs to attract females and defend territories. Similarly, in zebra finches, the number of new neurons in HVC is correlated with song quality (Pytte et al., 2011, 2012). In contrast, the total number of new HVC neurons in our study did not correlate with song stereotypy. New neurons that are not labeled with retrograde tracer may not yet have made connections with RA or may be interneurons (i.e., neurons not directly involved in song production).

\section{Hormones support circuit regeneration}

Annual changes in circulating $\mathrm{T}$ levels in adult white-crowned sparrows drive the seasonal changes in HVC and RA summarized in Figure 7 (for an extended discussion of this model, see Brenowitz and Larson, 2015). Briefly, early in the breeding season, circulating $\mathrm{T}$ levels increase and trigger a trophic cascade. With this trophic support, more newborn HVC neurons survive and total neuron number increases. In the present study, we showed that many of these new neurons grow axons to RA and reconstruct the HVC-RA projection, which is associated with the frequent production of stereotyped, longer song. When the breeding season ends, plasma $\mathrm{T}$ drops to basal levels, trophic support is withdrawn, and many newborn and mature HVC neurons undergo apoptosis. We showed in the current study that up to half of the $\mathrm{HVC}_{\mathrm{RA}}$ neurons are lost and this circuit degenerates. Song becomes less stereotyped, shorter, and less frequent. This cycle repeats annually in adult sparrows. Similarly, steroid hormones support the survival of new neurons in the mammalian dentate gyrus (Mahmoud et al., 2016). In canaries, $T$ increases the survival of new HVC neurons, and this is mediated by BDNF (Rasika et al., 1994, 1999).

In conclusion, we showed that there is extensive plasticity of a telencephalic long-range neural circuit in adult white-crowned sparrows. The HVC-RA circuit degenerates in nonbreeding birds following the death of up to half of its neurons, and is reconstructed in breeding birds by the integration of newborn $\mathrm{HVC}_{\mathrm{RA}}$ neurons. This circuit is important in the motor production of learned song, and the stereotypy with which birds sing changes as the HVC-RA circuit degenerates and regenerates seasonally. The reconstruction of this circuit in breeding birds correlates with plasma $\mathrm{T}$ levels, requires the integration of adult-born projection neurons, and contributes to birds' ability to produce stereotyped song. This study demonstrates that steroid hormones can help reestablish functional neuronal circuits following degeneration in the adult brain.

\section{References}

Absil P, Pinxten R, Balthazart J, Eens M (2003) Effect of age and testosterone on autumnal neurogenesis in male European starlings (Sturnus vulgaris). Behav Brain Res 143:15-30. CrossRef Medline

Alvarez-Buylla A, Kirn JR, Nottebohm F (1990) Birth of projection neurons in adult avian brain may be related to perceptual or motor learning. Science 249:1444-1446. CrossRef Medline

Alvarez-Buylla A, Ling CY, Nottebohm F (1992) High vocal center growth and its relation to neurogenesis, neuronal replacement and song acquisition in juvenile canaries. J Neurobiol 23:396-406. CrossRef Medline

Balthazart J, Ball GF (2016) Endocrine and social regulation of adult neurogenesis in songbirds. Front Neuroendocrinol 41:3-22. CrossRef Medline

Bentley GE, Audage NC, Hanspal EK, Ball GF, Hahn TP (2003) Photoperiodic response of the hypothalamo-pituitary-gonad axis in male and female canaries, Serinus canaria. J Exp Zool A Comp Exp Biol 296:143-151. CrossRef Medline

Brainard MS, Doupe AJ (2013) Translating birdsong: songbirds as a model for basic and applied medical research. Annu Rev Neurosci 36:489-517. CrossRef Medline

Brenowitz EA (1981) Territorial song as a flocking signal in red-winged blackbirds (Agelaius phoeniceus). Anim Behav 29:641-642. CrossRef

Brenowitz EA, Larson TA (2015) Neurogenesis in the adult avian songcontrol system. Cold Spring Harb Perspect Biol 7:piia019000. CrossRef Medline

Brown SD, Johnson F, Bottjer SW (1993) Neurogenesis in adult canary telencephalon is independent of gonadal hormone levels. J Neurosci 13: 2024-2032. Medline

Cohen J (1988) Statistical power analysis for the behavioral sciences, Ed 2. Hillsdale, NJ: Lawrence Erlbaum.

De Marchis S, Bovetti S, Carletti B, Hsieh YC, Garzotto D, Peretto P, Fasolo A, Puche AC, Rossi F (2007) Generation of distinct types of periglomerular olfactory bulb interneurons during development and in adult mice: implication for intrinsic properties of the subventricular zone progenitor population. J Neurosci 27:657-664. CrossRef Medline

Goldman SA, Nottebohm F (1983) Neuronal production, migration, and differentiation in a vocal control nucleus of the adult female canary brain. Proc Natl Acad Sci U S A 80:2390-2394. CrossRef Medline

Johnson F, Sablan MM, Bottjer SW (1995) Topographic organization of a forebrain pathway involved with vocal learning in zebra finches. J Comp Neurol 358:260-278. CrossRef Medline

Kempermann G, Chesler EJ, Lu L, Williams RW, Gage FH (2006) Natural variation and genetic covariance in adult hippocampal neurogenesis. Proc Natl Acad Sci U S A 103:780-785. CrossRef Medline

Kirn JR, Nottebohm F (1993) Direct evidence for loss and replacement of projection neurons in adult canary brain. J Neurosci 13:1654-1663. Medline

Kirn JR, Alvarez-Buylla A, Nottebohm F (1991) Production and survival of projection neurons in a forebrain vocal center of adult male canaries. J Neurosci 11:1756-1762. Medline

Larson TA, Thatra NM, Lee BH, Brenowitz EA (2014) Reactive neurogenesis in response to naturally occurring apoptosis in an adult brain. J Neurosci 34:13066-13076. CrossRef Medline

Leitner S, Van't Hof TJ, Gahr M (2003) Flexible reproduction in wild canaries is independent of photoperiod. Gen Comp Endocrinol 130:102-108. CrossRef Medline

Lledo PM, Alonso M, Grubb MS (2006) Adult neurogenesis and functional plasticity in neuronal circuits. Nat Rev Neurosci 7:179-193. CrossRef Medline

Luo L, O'Leary DD (2005) Axon retraction and degeneration in development and disease. Annu Rev Neurosci 28:127-156. CrossRef Medline

Ma L, Wu Y, Qiu Q, Scheerer H, Moran A, Yu CR (2014) A developmental switch of axon targeting in the continuously regenerating mouse olfactory system. Science 344:194-197. CrossRef Medline

Mahmoud R, Wainwright SR, Galea LA (2016) Sex hormones and adult hippocampal neurogenesis: regulation, implications, and potential mechanisms. Front Neuroendocrinol 41:129-152. CrossRef Medline 
Marler P, Tamura M (1964) Culturally transmitted patterns of vocal behavior in sparrows. Science 146:1483-1486. CrossRef Medline

Meitzen J, Thompson CK, Choi H, Perkel DJ, Brenowitz EA (2009) Time course of changes in Gambel's white-crowned sparrow song behavior following transitions in breeding condition. Horm Behav 55:217-227. CrossRef Medline

Nelson DA (2007) Segregation of information in a complex acoustic signal: individual and dialect identity in white-crowned sparrow song. Anim Behav 74:1073-1084. CrossRef

Nottebohm F (1985) Neuronal replacement in adulthood. Ann N Y Acad Sci 457:143-161. CrossRef Medline

Nottebohm F, O’Loughlin B, Gould K, Yohay K, Alvarez-Buylla A (1994) The life span of new neurons in a song control nucleus of the adult canary brain depends on time of year when these cells are born. Proc Natl Acad Sci U S A 91:7849-7853. CrossRef Medline

Ölveczky BP, Otchy TM, Goldberg JH, Aronov D, Fee MS (2011) Changes in the neural control of a complex motor sequence during learning. J Neurophysiol 106:386-397. CrossRef Medline

Paton JA, Nottebohm FN (1984) Neurons generated in the adult brain are recruited into functional circuits. Science 225:1046-1048. CrossRef Medline

Pytte C, Yu YL, Wildstein S, George S, Kirn JR (2011) Adult neuron addition to the zebra finch song motor pathway correlates with the rate and extent of recovery from botox-induced paralysis of the vocal muscles. J Neurosci 31:16958-16968. CrossRef Medline

Pytte CL, George S, Korman S, David E, Bogdan D, Kirn JR (2012) Adult neurogenesis is associated with the maintenance of a stereotyped, learned motor behavior. J Neurosci 32:7052-7057. CrossRef Medline

Rasika S, Nottebohm F, Alvarez-Buylla A (1994) Testosterone increases the recruitment and/or survival of new high vocal center neurons in adult female canaries. Proc Natl Acad Sci U S A 91:7854-7858. CrossRef Medline

Rasika S, Alvarez-Buylla A, Nottebohm F (1999) BDNF mediates the effects of testosterone on the survival of new neurons in an adult brain. Neuron 22:53-62. CrossRef Medline

Reiner A, Veenman CL, Medina L, Jiao Y, Del Mar N, Honig MG (2000) Pathway tracing using biotinylated dextran amines. J Neurosci Methods 103:23-37. CrossRef Medline

Reiner A, Perkel DJ, Mello CV, Jarvis ED (2004) Songbirds and the revised avian brain nomenclature. Ann N Y Acad Sci 1016:77-108. CrossRef Medline

Scott BB, Lois C (2007) Developmental origin and identity of song system neurons born during vocal learning in songbirds. J Comp Neurol 502: 202-214. CrossRef Medline

Scott BB, Gardner T, Ji N, Fee MS, Lois C (2012) Wandering neuronal migration in the postnatal vertebrate forebrain. J Neurosci 32:1436-1446. CrossRef Medline
Scotto-Lomassese S, Rochefort C, Nshdejan A, Scharff C (2007) HVC interneurons are not renewed in adult male zebra finches. Eur J Neurosci 25:1663-1668. CrossRef Medline

Smith GT, Brenowitz EA, Wingfield JC, Baptista LF (1995) Seasonal changes in song nuclei and song behavior in Gambel's white-crowned sparrows. J Neurobiol 28:114-125. CrossRef Medline

Smith GT, Brenowitz EA, Wingfield JC (1997) Roles of photoperiod and testosterone in seasonal plasticity of the avian song control system. J Neurobiol 32:426-442. CrossRef Medline

Soha JA, Marler P (2000) A species-specific acoustic cue for selective song learning in the white-crowned sparrow. Anim Behav 60:297-306. CrossRef Medline

Sullivan GM, Feinn R (2012) Using effect size: or why the p value is not enough. J Grad Med Educ 4:279-282. CrossRef Medline

Thompson CK, Brenowitz EA (2008) Caspase inhibitor infusion protects an avian song control circuit from seasonal-like neurodegeneration. J Neurosci 28:7130-7136. CrossRef Medline

Thompson CK, Bentley GE, Brenowitz EA (2007) Rapid seasonal-like regression of the adult avian song control system. Proc Natl Acad Sci U S A 104:15520-15525. CrossRef Medline

Toni N, Laplagne DA, Zhao C, Lombardi G, Ribak CE, Gage FH, Schinder AF (2008) Neurons born in the adult dentate gyrus form functional synapses with target cells. Nat Neurosci 11:901-907. CrossRef Medline

Tramontin AD, Brenowitz EA (1999) A field study of seasonal neuronal incorporation into the song control system of a songbird that lacks adult song learning. J Neurobiol 40:316-326. CrossRef Medline

Tramontin AD, Smith GT, Breuner CW, Brenowitz EA (1998) Seasonal plasticity and sexual dimorphism in the avian song control system: stereological measurement of neuron density and number. J Comp Neurol 396:186-192. CrossRef Medline

Tramontin AD, Hartman VN, Brenowitz EA (2000) Breeding conditions induce rapid and sequential growth in adult avian song control circuits: a model of seasonal plasticity in the brain. J Neurosci 20:854-861. Medline

Tramontin AD, Wingfield JC, Brenowitz EA (2003) Androgens and estrogens induce seasonal-like growth of song nuclei in the adult songbird brain. J Neurobiol 57:130-140. CrossRef Medline

Walton C, Pariser E, Nottebohm F (2012) The zebra finch paradox: song is little changed, but number of neurons doubles. J Neurosci 32:761-774. CrossRef Medline

Wingfield JC, Farner DS (1978) The annual cycle of plasma irLH and steroid hormones in feral populations of the white-crowned sparrow, Zonotrichia leucophrys gambelii. Biol Reprod 19:1046-1056. CrossRef Medline

Wissman AM, Brenowitz EA (2009) The role of neurotrophins in the seasonal-like growth of the avian song control system. J Neurosci 29: 6461-6471. CrossRef Medline

Yip ZC, Miller-Sims VC, Bottjer SW (2012) Morphology of axonal projections from the high vocal center to vocal motor cortex in songbirds. J Comp Neurol 520:2742-2756. CrossRef Medline 